\title{
PENGARUH EKSTRAK BUAH LERAK (Sapindus rarak) DAN BEBERAPA ADJUVAN TERHADAP PERKECAMBAHAN GULMA Fimbristylis miliacea
}

\author{
Effect of Fruit Extract of Sapindus rarak and Adjuvants on Germination of \\ Fimbristylis miliacea \\ Hidayat Pujisiswanto ${ }^{1 *}$, Yayuk Nurmiaty ${ }^{2}$, Nanik Sriyani ${ }^{1}$, Annisa Afrima ${ }^{2}$ \\ ${ }^{1}$ Jurusan Agronomi dan Hortikultura, Fakultas Pertanian, Universitas Lampung \\ ${ }^{2}$ Jurusan Agroteknologi, Fakultas Pertanian, Universitas Lampung \\ Jl. Sumantri Brojonegoro No 1 Gedung Meneng, Bandar Lampung 35145 \\ *E-mail korespondensi: hidayat.pujisiswanto@fp.unila.ac.id
}

\begin{abstract}
ABSTRAK
Adjuvan merupakan bahan yang ditambahkan dalam formulasi untuk menambah efektivitas ekstrak buah lerak (Sapindus rarak) dalam menghambat perkecambahan gulma. Penelitian ini bertujuan untuk mengetahui jenis adjuvan dalam ekstrak buah lerak yang dapat meningkatkan penghambatan perkecambahan gulma Fimbristylis miliacea. Penelitian dilakukan pada bulan Desember 2019 sampai Maret 2020 di Laboratorium Gulma, Fakultas Pertanian, Universitas Lampung. Penelitian ini menggunakan Rancangan Acak Lengkap (RAL) unuk mengetahui jenis adjuvan yang diberikan pada esktrak buah lerak pada perkecambahan gulma $F$. miliacea dengan 4 ulangan. Perlakuan terdiri dari kontrol (aquades), ekstrak buah lerak + adjuvan VCO, ekstrak buah lerak + adjuvan KAO, ekstrak buah lerak + adjuvan Polysorbate 80, dan ekstrak buah lerak. Digunakan uji Bartlett untuk menguji homogenitas ragam, jika asumsi analisis ragam terpenuhi, maka nilai tengah perlakuan dilanjutkan dengan uji Beda Nyata Terkecil (BNT) pada taraf 5\%. Hasil penelitian menunjukkan bahwa adjuvan dan tanpa adjuvan yang ditambahkan dalam ekstrak buah lerak pada konsentrasi 50\% (500 g/l) mampu menekan persentase perkecambahan dan kecepatan perkecambahan biji gulma Fimbristylis miliacea.
\end{abstract}

Kata kunci: adjuvan, ekstrak buah lerak, Fimbristylis miliacea, gulma

\begin{abstract}
Adjuvant is an ingredient added in a formulation to increase the effectiveness of Sapindus rarak fruit extract in inhibiting weeds. This study aims to determine the type of adjuvant in Sapindus rarak fruit extract that can increase the inhibition of germination of Fimbristylis miliacea. The research was conducted from December 2019 to March 2020 in the Weed Laboratory, Faculty of Agriculture, University of Lampung. This study used a Completely Randomized Design (CRD) to determine the type of adjuvant given to $S$. rarak fruit extract on $F$. miliacea germination with 4 replications. The treatments consisted of control (aquadest), S. rarak fruit extract $+V C O$ adjuvant, $S$. rarak fruit extract $+K A O$ adjuvant, S. rarak fruit extract + Polysorbate 80 adjuvant, and S. rarak fruit extract. The Bartlett test was used to test the homogeneity of variance, if the assumptions of the analysis of variance were met, then the mean value of the treatment was continued with the Least Significant Difference (LSD) test at the 5\% level. The results showed that adjuvants and without adjuvants added to $S$. rarak fruit extract at a concentration of $50 \%(500 \mathrm{~g} / \mathrm{l})$ were able to suppress the percentage of germination and the speed of germination of Fimbristylis miliacea seeds.
\end{abstract}

Key words: adjuvants, Sapindus rarak fruit extract, Fimbristylis miliacea, weed 


\section{PENDAHULUAN}

Kehadiran gulma selama proses budidaya tanaman dapat menyebabkan terjadinya kompetisi dengan tanaman dalam memperebutkan sarana tumbuh seperti unsur hara, air, cahaya, dan ruang tumbuh. Gulma Fimbristylis miliacea merupakan salah satu gulma yang paling dominan tumbuh di pertanaman padi sawah pada fase vegetatif dan fase generatif. Perkecambahan biji paling baik pada saat penyinaran matahari penuh dan tidak adanya dormansi pada biji. Secara umum, kerugian tanaman budidaya yang disebabkan gulma $F$. milliace mampu menurunkan hasil produksi tanaman padi hingga $42 \%$ sehingga gulma ini harus dikendalikan (Miranda, 2011). Oleh karena itu, perlu dilakukan pengendalian secara tepat.

Pengendalian gulma yang efektif adalah dengan cara kimiawi menggunakan herbisida. Metode kimiawi dinilai lebih praktis dan menguntungkan dibandingkan dengan metode lain. Akan tetapi, konsekuensi dari pemakaian herbisida yang sama (sama jenis bahan aktif atau sama cara kerja) secara berulang-ulang dalam periode yang lama pada suatu areal dapat menimbulkan masalah pada areal tersebut, yaitu terjadi dominansi populasi gulma resisten terhadap herbisida (Hambali et al., 2015). Salah satu cara yang dapat dilakukan untuk menekan penggunaan herbisida kimia sintetik yakni dengan menggunakan herbisdia yang terbuat dari bahan nabati salah satunya dari esktrak buah lerak.

Buah lerak merupakan tanaman yang banyak mengandung senyawa fitokimia berupa alkaloid, tanin, flavonoid, polifenol, dan saponin (Udarno, 2009). Penelitian yang dilakukan oleh Putri (2019), menunjukkan bahwa ekstrak buah lerak pada konsentrasi $25-100 \%$ dengan dosis $5 \mathrm{ml} /$ cawan petri mampu menghambat perkecambahan biji gulma $F$. miliacea tetapi perlu adanya adanya formulasi ekstrak buah lerak dan adjuvan diharapkan dapat meningkatkan efektivitas dari eskstrak buah lerak dalam menekan perkecambahan gulma $F$. miliacea. Pujisiswanto at al. (2020) menyatakan aplikasi ekstrak buah lerak konsentrasi 50\% $(500 \mathrm{~g} / \mathrm{l})$ dengan penambahan adjuvan $\mathrm{VCO}$, KAO, dan Tween pada konsentrasi 2\% (20 $\mathrm{ml} / \mathrm{l}$ ) mampu menghambat perkecambahan gulma Ludwigia octovalvis sebesar 95\%$100 \%$.

Peningkatan efektivitas herbisida dapat dilakukan dengan bahan tambahan yang diaplikasikan secara bersamaan. Adjuvan merupakan bahan yang ditambahkan dalam formulasi untuk menambah efektivitas buah lerak. Dalam hal ini, adjuvan memiliki kelebihan untuk meningkatkan kemampuan mendispersi atau mengemulsi, menyerap, menyebarkan, dan menempel (Miller dan Westra, 1998). Adjuvan seperti KAO, Polysorbate 80, dan Virgin Coconut Oil (VCO) memiliki potensi untuk meningkatkan kemampuan herbisida nabati dalam mengendalikan gulma. Oleh karena itu, tujuan penelitian dengan penambahan adjuvan diharapkan dapat meningkatkan efektivitas dari eskstrak buah lerak dalam menghambat perkecambahan gulma $F$. miliacea.

\section{METODE PENELITIAN}

Penelitian dilaksanakan di Laboratorium Gulma Fakultas Pertanian Universitas Lampung pada bulan Desember 2019 sampai Maret 2020. Bahan yang digunakan yaitu 50\% (500 g/l) aguades e kstrak buah lerak, adjuvan Polysorbate 80, adjuvan KAO, adjuvan VCO (Virgin Coconut Oil), biji gulma $F$. miliacea, aquades, dan label. Alat yang digunakan adalah erlenmeyer, timbangan, blender, oven, baskom, pengaduk, saringan, gelas ukur, cawan petri, plastik wrapping, gunting, label, kertas merang, spons, dan hand sprayer.

Rancangan yang digunakan menggunakan Rancangan Acak Lengkap (RAL) dengan faktor tunggal. Masingmasing perlakuan pada cawan petri diulang sebanyak 4 kali sehingga diperoleh 20 satuan 
percobaan. Perlakuan terdiri: Aquades (kontrol), ekstrak buah lerak + adjuvan VCO, ekstrak buah lerak + adjuvan KAO, ekstrak buah lerak + adjuvan Polysorbate 80 dan ekstrak buah lerak murni. Homogenitas ragam data diuji dengan uji Barlett. Jika asumsi analisis ragam terpenuhi, maka nilai tengah perlakuan dilanjutkan dengan uji Beda Nyata Terkecil (BNT) pada taraf 5\%.

Pada uji perkecambahan dilakukan menggunakan cawan petri berukuran diameter dan tinggi $(10 \mathrm{~cm} \times 2 \mathrm{~cm})$ yang telah dimasukan media tanam berupa spons dan kertas merang. Pada setiap cawan petri dilakukan penyemaian biji gulma Fimbristylis miliacea sebanyak 100 biji, kemudian diaplikasi 1 (satu) kali selama penelitian dengan $5 \mathrm{ml}$ larutan ekstrak buah lerak dan adjuvan ke dalam cawan petri sesuai dengan perlakuan yang telah ditentukan Variabel yang diamati pada uji perkecambahan yaitu persentase berkecambah dan kecepatan perkecambahan. Pengamatan dilakukan selama 2 minggu dan pengamatan dilakukan setiap hari.

Menurut Talukdar (2011), perentase perkecambahan ditentukan dengan jumlah biji yang berkecambah normal, dengan rumus sebagai berikut:

$(\mathrm{PKC})=\sum \mathrm{Bk} / \sum \mathrm{TB} \times 100$,

Dimana $\sum$ Bk = jumlah biji berkecambah; $\sum \mathrm{TB}=$ jumlah total biji

Kecepatan berkecambah yang dihitung adalah benih yang berkecambah dari hari pengamatan ke-1 sampai dengan hari terakhir. Dengan penghitungan kecambah normal pada setiap pengamatan dibagi dengan etmal $(1=24$ jam). Menurut Sadjad et al. (1999) dan Widajati (2013), kecepatan berkecambah menjabarkan parameter vigor dan rumus kecepatan berkecambah sebagai berikut :

$$
\mathrm{Kct}=\sum_{\mathrm{i}=0}^{\mathrm{i}=\mathrm{n}} \% \mathrm{Kn} / \text { etmal }
$$

dimana

$\mathrm{Kn}=$ Kecambah normal $\mathrm{i}=$ hari pengamatan

etmal $=24$ jam

\section{HASIL DAN PEMBAHASAN}

Hasil penelitian yang telah dilakukan menunjukkan bahwa aplikasi ekstrak buah lerak dengan penambahan adjuvan VCO, $\mathrm{KAO}$, dan Polysorbate 80 dapat menekan presentase perkecambahan, dan kecepatan perkecambahan gulma Fimbristylis miliacea. Jenis adjuvan yang digunakan dalam penelitian ini tidak menunjukkan perbedaan antar-adjuvan dalam ekstrak buah lerak bahkan tanpa adjuvan juga menghasilkan hasil yang setara.

\section{Presentase perkecambahan gulma.}

Hasil penelitian uji perkecambahan yang dilakukan pada 1 dan 2 MSA menunjukkan aplikasi ekstrak buah lerak dengan penambahan adjuvan KAO, VCO, dan Polysorbate atau tanpa adanya penambahan adjuvan dapat menghambat perkecambahan gulma Fimbristylis miliacea (Tabel 1). Selain itu dapat dilihat pada Gambar 1, perlakuan ekstrak buah lerak dengan adjuvan atau tanpa adjuvan menunjukkan perkecambahan 0,25 - 0,75\%, sedangkan kontrol (aquades) menunjukkan perkecambahan sebesar 76,50\%.

Pengapilkasian adjuvan VCO, KAO, dan Polysorbate yang ditambahkan ke dalam ekstrak buah lerak memiliki kecenderungan yang setara dalam menekan perkecambahan gulma dibandingkan dengan ekstrak buah lerak tanpa adjuvan. Buah lerak banyak mengandung senyawa fenol, polifenol, dan saponin. Hal ini telah dibuktikan oleh Hoagland et al. (1996), yang menyatakan bahwa senyawa saponin telah diuji pada berbagai jenis gulma dan terbukti dapat mengurangi keberadaan gulma. Menurut Ohana et al. (1998), saponin juga telah terbukti mempengaruhi sintesis selulosa pada tumbuhan. Menurut Einheillig (2004), senyawa fenolik yang tergolong alelopati merupakan turunan dari asam sinamat, asam 
benzoat, asam kumarat, tanin, polifenol komplek, dan flavonoid tertentu.

Tabel 1. Pengaruh ekstrak buah lerak dengan penambahan adjuvan pada persentase perkecambahan biji gulma Fimbristylis miliacea.

\begin{tabular}{|c|c|c|c|c|}
\hline \multirow{3}{*}{ Perlakuan } & \multicolumn{2}{|c|}{$1 \mathrm{MSA}$} & \multicolumn{2}{|c|}{$2 \mathrm{MSA}$} \\
\hline & Asli & $\operatorname{Arcsin}(\sqrt{x+0,5)}$ & Asli & $\operatorname{Arcsin}(\sqrt{x}+0,5)$ \\
\hline & \multicolumn{4}{|c|}{$(\%)$} \\
\hline Aquades (Kontrol) & 62,00 & 52,45 a & 76,50 & 61,48 a \\
\hline Ekstrak lerak+VCO & 0,25 & $1,93 \mathrm{~b}$ & 0,25 & $3,36 \mathrm{~b}$ \\
\hline Ekstrak lerak+KAO & 0,25 & $1,93 \mathrm{~b}$ & 0,50 & $4,55 \mathrm{~b}$ \\
\hline Ekstrak lerak+Polysorbate 80 & 0,50 & $3,37 \mathrm{~b}$ & 0,50 & $4,55 \mathrm{~b}$ \\
\hline Ekstrak lerak murni & 0,75 & $4,80 \mathrm{~b}$ & 0,75 & $5,47 \mathrm{~b}$ \\
\hline BNT 5\% & & 4,49 & & 5,01 \\
\hline
\end{tabular}

Keterangan: Nilai rata-rata yang diikuti oleh huruf yang sama dalam kolom yang sama tidak nyata pada BNT 5\%.
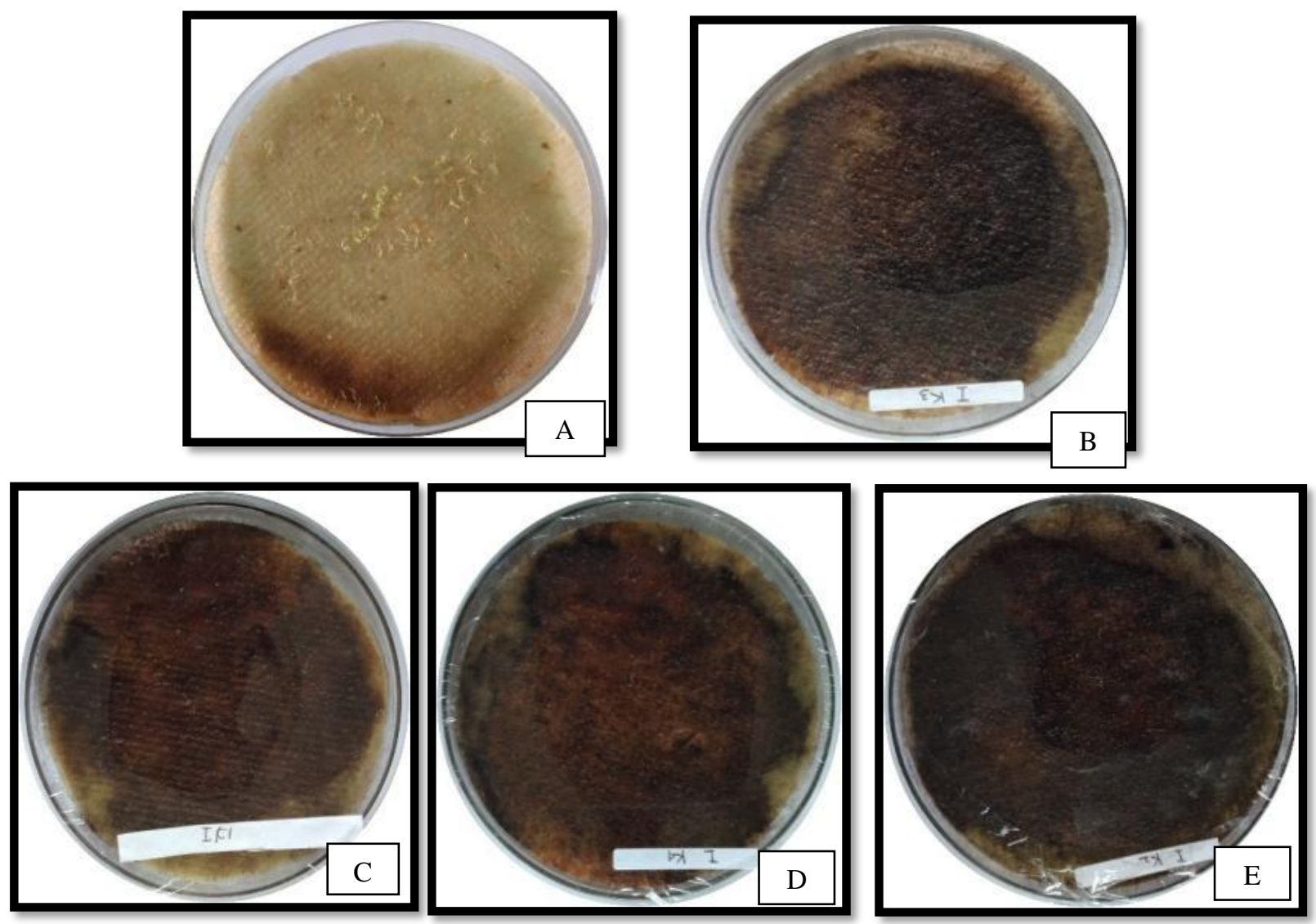

Gambar 1. Pengaruh ekstrak buah lerak dengan penambahan adjuvan pada perkecambahan gulma $F$. miliacea: (A) aquades (kontrol), (B) Ekstrak lerak+VCO, (C) Ekstrak lerak+KAO, (D) Ekstrak lerak + Polisorbate 80; (E) Ekstrak lerak murni 
Gejala umum yang ditimbulkan oleh pengaruh alelopati pada tanaman adalah terhambatnya perkecambahan biji tanaman. Senyawa alelopati dapat mengakibatkan aktivitas enzim terganggu sehingga perkecambahan terhambat bahkan biji tidak mampu berkecambah. Selain itu, penghambatan perkecambahan biji juga terjadi karena permeabilitas membran sel yang menurun, pembelahan, dan pembesaran sel yang terhambat, dan menurunnya kemampuan dalam penyerapan air, dan hara terlarut. Hambatan perkecambahan oleh alelopati dapat terjadi melalui hambatan pada pembelahan sel, pengambilan mineral, respirasi, penutupan stomata, sintesis protein, dan aktivitas enzim (Pebriani et al, 2013).

\section{Kecepatan perkecambahan gulma Fimbristylis miliacea.}

Hasil penelitian menunjukan bahwa pengaplikasian ekstrak buah lerak dengan penambahan adjuvan (VCO, KAO, dan Polysorbate) atau tanpa adanya penambahan adjuvan (ekstrak buah lerak murni) menekan kecepatan perkecambahan biji gulma Fimbristylis miliacea. Pengaplikasian ini dapat mempengaruhi kecepatan perkecambahan biji gulma Fimbristylis miliacea sampai 2 MSA. Berbeda dengan pengaplikasian aquades (kontrol) kecepatan perkecambahan biji gulma dapat mencapai $12,91 \% \mathrm{KN} /$ etmal (Tabel 2).

Tabel 2. Pengaruh ekstrak buah lerak dengan penambahan adjuvan lerak pada kecepatan perkecambahan biji gulma Fimbristylis miliacea.

\begin{tabular}{lrrr}
\hline & \multicolumn{4}{c}{ Kecepatan Perkecambahan } \\
\cline { 2 - 5 } \multicolumn{1}{c}{ Perlakuan } & Asli & Arcsin $(\sqrt{\mathrm{x}+0,5)}$ \\
& \multicolumn{4}{c}{$(\%$ KN/etmal $)$} \\
\cline { 2 - 5 } & 12,91 & 21,51 & $\mathrm{a}$ \\
& 0,07 & 1,04 & $\mathrm{~b}$ \\
Aquades (Kontrol) & 0,08 & 1,55 & $\mathrm{~b}$ \\
Ekstrak lerak + VCO & 0,09 & 1,73 & $\mathrm{~b}$ \\
Ekstrak lerak +KAO & 0,13 & 2,27 & $\mathrm{~b}$ \\
Ekstrak lerak+Polysorbte80 & & 2,12 \\
Ekstrak lerak murni & & & \\
\hline \multicolumn{1}{c}{ BNT 5\% } & & & \\
\hline
\end{tabular}

Keterangan: Nilai rata-rata yang diikuti oleh huruf yang sama dalam kolom yang sama tidak nyata pada BNT 5\%

Menurut Sadjad (1993), benih dapat dikategorikan berviabilitas tinggi jika memiliki perkecambahan $>80 \%$, sedangkan benih dikategorikan berviabilitas rendah jika daya berkecambahnya $<60 \%$. Selain itu, kecepatan perkecambahan biji gulma juga relatif lambat yaitu hanya $12,91 \%$. Diungkapkan oleh Sadjad (1993), memberi kriteria bila benih mempunyai kecepatan tumbuh lebih besar dari 30 persen memiliki vigor kecepatan tumbuh yang kuat, sedangkan untuk gulma teki ini belum ada refrensinya. Nilai daya berkecambah gulma
F. miliacea yang diuji sebesar $76,50 \%$ kemungkinan masih bisa lebih tinggi. Hal ini diduga disebabkan oleh kondisi lingkungan perkecambahan biji gulma yang belum optimum atau cawan petri sehingga perlu diletakkan dalam media pengecambah benih yang kondisi lingkungannya optimum untuk teki tersebut 


\section{KESIMPULAN}

Pengaruh adjuvan dan tanpa adjuvan yang ditambahkan ke dalam ekstrak buah lerak pada konsentrasi 50\% (500 g/l) mampu menekan persentase perkecambahan dan kecepatan perkecambahan biji gulma Fimbristylis miliace

\section{DAFTAR PUSTAKA}

Einhelig, F.A. 2004. Allelopathy: Organisms, Processes, and Applications. Washington DC: American Chemical Society. p 217 238.

Hambali, D., E. Purba, dan E. H. Kardhinata. 2015. Dose response biotipe rumput belulang (Eleusine indica (L.) Gaertn.) resisten Parakuat terhadap Parakuat, Diuron, dan Ametrin. Jurnal Online Agroekoteknologi. 3 (2): 574-580.

Hoagland, E., M.Z. Robert, and K.N. Reddy. 1996. Saponins Used in Food and Agriculture. Pienum Press. New York. $402 \mathrm{p}$.

Miller, P., dan P. Westra. 1998. Herbicide Surfactants and Adjuvants. Colorado State University. Colorado.

Miranda, N. 2011. Eksplorasi dan identifikasi gulma pada padi sawah lokal (Oryza sativa L.) di Kota Padang. Jerami. 4(1): 19.

Ohana, P., D.P. Delmer, R.W. Carlson, J. Glushka, P. Azadi, T. Bacic, M. Benziman. 1998. Identification of a novel triterpenoid saponin from Pisum sativum as a specific inhibitor of the diguanylate cyclase of Acetobacter xylinum. Plant Cell Physiol. 39:144-152.

Pebriani, R. Linda, dan Mukarlina. 2013. Potensi ekstrak daun sembung rambat (Mikania micrantha H.B.K) sebagai bioherbisida terhadap gulma Maman Ungu (Cleome rutidosperma D.C.) dan rumput Bahia (Paspalum notatum F.). Protobiont. 2 (2): 32-38.

Pujisiswanto, H., Sunyoto., N. Sriyani, dan M. T. Pratiwi. 2020. Efektivitas formulasi bioherbisida ekstrak buah lerak dengan penambahan adjuvan terhadap perkecambahan gulma Ludwigia octovalvis. Jurnal Agrotropika. 19 (2): 96-101.

Putri, D. U. 2019. Pengaruh ekstrak buah lerak (Sapindus rarak DC.) sebagai herbisida nabati terhadap perkecambahan dan pertumbuhan gulma Fimbristylis miliacea. Skripsi Jurusan Agroteknologi. Universitas Lampung.

Sadjad, S, E. Muniarti, dan S. Ilyas. 1999. Parameter Pengujian Vigor Benih Komparatif ke Simulatif. Jakarta: PT. Grasindo.

Sadjad, S. 1993. Dari Benih Kepada Benih. Gramedia Widiasarana Indonesia. Jakarta. $144 \mathrm{hlm}$.

Talukdar, D. 2011. Effect of arsenic-induced toxicity on morphological traits of Trigonella faenum-graecum $\mathrm{L}$ and Lathyrus satyvus L during germination and early seedling growth. Current Reseach Journal of Biological Sciences. 3(2): 116 - 123.

Udarno, L. 2009. Lerak (Sapindus rarak) tanaman industri pengganti sabun. Warta Penelitian dan Pengembangan Tanaman Industri. 15 (2): 7-10.

Widajati, E. 2013. Metode Pengujian Mutu Benih (Dasar Ilmu dan Teknoligi Benih). Bogor: IPB Press 